\title{
ANTIBACTERIAL AND ANTI-BIOFILM ACTIVITY OF GINGER (Zingiber officinale (Roscoe)) ETHANOLIC EXTRACT
}

\author{
Miloš Nikolić*, Sava Vasić, Jelena Đurđević, Olgica Stefanović and Ljiljana Čomić \\ Laboratory of Microbiology, Department of Biology and Ecology, Faculty of Science, \\ University of Kragujevac, Radoja Domanovica 12, 34000 Kragujevac, Republic of Serbia \\ "Corresponding author, e-mail: mnikolic225@gmail.com
}

(Received March 31, 2014)

\begin{abstract}
The antibacterial and anti-biofilm activity of ethanolic extract from the rhizome of Zingiber officinale were evaluated. In vitro antibacterial activity was investigated by microdilution method. Minimum inhibitory concentration (MIC) and minimum bactericidal concentration (MBC) have been determined. The values were in the range from 0.0024 to $>20 \mathrm{mg} / \mathrm{ml}$. The most sensitive bacteria were Gram-positive bacteria: Staphylococcus aureus and Staphylococcus aureus ATCC 25923. Anti-biofilm activity was tested by crystal violet assay. Pseudomonas aeruginosa ATCC 27853, Proteus mirabilis and Escherichia coli ATCC 25922 were used as the test organisms. Ethanolic extract showed the best result on Proteus mirabilis biofilm where biofilm inhibitory concentration $\left(\mathrm{BIC}_{50}\right)$ was $19 \mathrm{mg} / \mathrm{ml}$.
\end{abstract}

Keywords: Zingiber officinale, antibacterial activity, biofilm, ethanolic extract.

\section{INTRODUCTION}

Biofilm is a community of microbial cells attached to the surface and is embedded in the extracellular polymeric substances (EPS) (DONLAN, 2002). Biofilms are sources of diverse problems in food industry, medicine and everyday life. The presence of biofilms in food processing environments is a potential source of contamination that may lead to food spoilage and disease transmission (HOOD and ZotTOLA, 1995; FrANK, 2001). Bacteria included in biofilm structure are generally more resistant to antimicrobial agents than planktonic cells (LEWIS, 2001; DONLAN and COSTERTON, 2002). The effects of plant extracts to prevent biofilm formation and adherence have been showed in earlier studies (QUAVE et al., 2008; SANDASI et al., 2010).

Ginger (Zingiber officinale Roscoe, fam. Zingiberaceae) is a perennial herb, with leafy stem up to $60 \mathrm{~cm}$. The rhizome is horizontal, branched, fleshy, aromatic, white or yellowish to brown. Leaves are narrowly or linear-lanceolate, up to $20 \mathrm{~cm}$ long and $1.5-2 \mathrm{~cm}$ wide. Flowers are produced in a dense spike, yellow green with purple endings. This plant is widely distributed in South-Eastern Asia (Ross, 2005).

The rhizome is rich in the secondary metabolites such as phenolic compounds (gingerol, paradol and shogaoal), volatile sesquiterpenes (zingiberene and bisabolene) and monoterpenoids (curcumene and citral) (ALI et al., 2008). Previous studies have demonstrated that plant extracts and isolated compounds from $Z$. officinale possess strong antioxidant 
(STOILOVA et al., 2007), antibacterial, antifungal, anticancer and anti-inflammatory effects (HABIB et al., 2008). In food industry, both pathogenic and food spoilage bacteria can attach and form a biofilm on food contact surfaces and food product, on the other hand Z. officinale is widely used as spice, so the aim of this study was ginger effectiveness in preventing this problem through the evaluation of antibacterial activity of ethanolic extract of $Z$. officinale, as well as the effect of this extract on biofilm formation against Proteus mirabilis, Pseudomonas aeruginosa ATCC 27853 and Escherichia coli ATCC 25922.

\section{MATERIALS AND METHODS}

Chemicals
Ethanol was purchased from Zorka Pharma (Šabac, Serbia). Dimethyl sulfoxide (DMSO) was purchased from Centrohem (Stara Pazova, Serbia). Resazurin was obtained from Alfa Aesar $\mathrm{GmbH} \& \mathrm{Co}$. (KG, Karlsruhe, Germany) and crystal violet stain was from Fluka AG (Buchs, Switzerland). Nutrient media, a Mueller-Hinton broth was purchased from Liofilchem (Italy). An antibiotic, tetracycline was from Sigma Chemicals Co. (St. Louis, MO, USA).

\section{Plant material and extraction}

Z. officinale (rhizomes) was obtained commercially (Metro, imported from China). Dried, ground rhizomes were extracted with ethanol by maceration. $50 \mathrm{~g}$ of plant material was soaked with $200 \mathrm{ml}$ of ethanol for $24 \mathrm{~h}$ at room temperature. After that the resulting extract was filtered through filter paper (Whatman no.1). The residue from the filtration was extracted again twice using the same procedure. The filtrates obtained were combined and then evaporated to dryness using a rotary evaporator at $40{ }^{\circ} \mathrm{C}$. Stock solutions of crude extract were obtained by dissolving in DMSO and then diluted into Mueller-Hinton broth to achieve a concentration of $10 \%$ DMSO.

\section{Test bacteria}

\section{Determination of antibacterial activity}

The list of tested bacteria is presented in Table 1. All clinical isolates were a generous gift from the Institute of Public Health, Kragujevac. The other bacteria were provided from a collection held by the Microbiology Laboratory, Faculty of Science, University of Kragujevac.

\section{Antibacterial assay}

Antibacterial activity was tested by determining the minimum inhibitory concentration (MIC) and minimum bactericidal concentration (MBC) using microdilution method with resazurin (SARKER et al., 2007). Bacterial suspensions were prepared by direct colony method. The turbidity of initial suspension was adjusted by comparing with $0.5 \mathrm{McF}$ arland's standard (ANDREWS, 2005). Initial bacterial suspensions contain about $10^{8}$ colony forming units $(\mathrm{CFU}) / \mathrm{ml}$ and then 1:100 diluted in sterile $0.85 \%$ saline. Twofold serial dilutions of plant extract were made in a concentration range from $20 \mathrm{mg} / \mathrm{ml}$ to $0.0012 \mathrm{mg} / \mathrm{ml}$ in sterile 96-well plates containing Mueller-Hinton broth. A $10 \mu \mathrm{l}$ of diluted bacterial suspension was added to each well to give a final concentration of $5 \times 10^{5} \mathrm{CFU} / \mathrm{ml}$. Finally, $10 \mu \mathrm{l}$ of resazurin solution, as an indicator of microbial growth, was added to each well. The inoculated plates were incubated at $37{ }^{\circ} \mathrm{C}$ for $24 \mathrm{~h}$. MIC was defined as the lowest concentration of tested compound that prevented resazurin color change from blue to pink.

MBC was determined by plating $10 \mu \mathrm{l}$ of samples from wells, where no indicator color change was recorded, on nutrient agar. At the end of the incubation period the lowest 
concentration with no growth (no colony) was defined as minimum bactericidal concentration.

Tetracycline, dissolved in nutrient liquid medium was used as positive control. Solvent control test was performed to study an effect of $10 \%$ DMSO on the growth of bacteria. It was observed that $10 \%$ DMSO did not inhibit the growth of bacteria. Each test included growth control and sterility control. All tests were performed in duplicate and MICs were constant.

\section{Test bacteria}

\section{Determination of anti-biofilm activity}

The bacteria chosen for anti-biofilm assay were: clinical isolate Proteus mirabilis and standard strains of Pseudomonas aeruginosa ATCC 27853 and Escherichia coli ATCC 25922.

\section{Biofilm formation assay and quantification}

The ability bacteria to form biofilms were assayed as described by O'TOOLE and KOLTER (1998) with some modifications. In sterile 96-well tissue culture plates (Sarstedt, Germany) containing $50 \mu \mathrm{l}$ of Mueller-Hinton broth per well, a $50 \mu \mathrm{l}$ of fresh bacterial suspension (1.0 McFarland) was added. After incubation at $37{ }^{\circ} \mathrm{C}$ for $48 \mathrm{~h}$, the content of each well was gently removed by tapping the plates. The wells were washed with $200 \mu \mathrm{l}$ of sterile saline to remove free-floating bacteria. Biofilms formed by adherent cells in plate were stained with $0.1 \%$ crystal violet and incubated at the room temperature for 20 minutes. Excess stain was rinsed off by thorough washing with deionized water and plates were fixed with 200 $\mu \mathrm{l}$ of $96 \%$ ethanol. Optical densities (OD) of stained adherent bacteria were measured at 630 $\mathrm{nm}$ using an ELISA microplate reader. All tests were performed in triplicate. The cut-off optical density (ODc) was defined as three standard deviations above the mean OD of the negative control (culture medium). Strains were classified as follows: OD $\leq$ ODc no biofilm producer, $\mathrm{ODc}<\mathrm{OD} \leq 2 \times \mathrm{ODc}$ weak biofilm producer, $2 \times$ ODc $<\mathrm{OD} \leq 4 \times$ ODc moderate biofilm producer and $4 \times$ ODc < OD strong biofilm producer (STEPANOVIĆ et al., 2000).

\section{Effect on biofilm formation}

A modified crystal violet assay was employed to test the effect of plant extract on biofilm formation. Twofold serial dilutions of plant extract were made in sterile 96-well tissue culture plates containing $50 \mu \mathrm{l}$ of Mueller-Hinton broth per well. The tested concentration range was from $20 \mathrm{mg} / \mathrm{ml}$ to $0.156 \mathrm{mg} / \mathrm{ml}$. A $50 \mu \mathrm{l}$ of fresh bacterial suspension (1.0 McFarland) was added to each well. Growth control (cells + broth), media control (only broth) and blank control (broth + extract) were included. After incubation at $37{ }^{\circ} \mathrm{C}$ for $48 \mathrm{~h}$, the biofilm biomass was assayed using the crystal violet staining assay as described above.

The percentage of biofilm inhibition was calculated using the following formula: [(OD growth control - OD sample) / OD growth control] $\times 100$. The biofilm inhibition concentration $\left(\mathrm{BIC}_{50}\right)$ was defined as the lowest concentration of extract that showed $50 \%$ inhibition on the biofilm formation (CHAIEB et al., 2011).

\section{Data analysis}

For comparison between samples, data was analyzed by the Student's t-test and the one-way analysis of variance (ANOVA). In all cases $p$ values $<0.05$ were considered statistically significant. All statistical analyses were performed using SPSS package. 


\section{RESULTS AND DISCUSSION}

\section{Antibacterial activity}

The results of in vitro antibacterial activity of ethanolic extract of Z. officinale are presented in Table 1. For comparison, the results of the activity of tetracycline are also listed in Table 1. The solvent (10\% DMSO) had no effect on the growth of tested bacteria.

Antibacterial activity of tested extract was evaluated by determining MICs and MBCs in relation to the 13 species of Gram-positive and Gram-negative bacteria. The MIC values of ethanolic extract of $Z$. officinale were in the range from $0.0024 \mathrm{mg} / \mathrm{ml}$ to $>20 \mathrm{mg} / \mathrm{ml}$, while the $\mathrm{MBC}$ values were in the range from $0.156 \mathrm{mg} / \mathrm{ml}$ to $>20 \mathrm{mg} / \mathrm{ml}$. The intensity of antibacterial activity varied depending on the species of bacteria.

Table 1. Antibacterial activity of ethanolic extract from Zingiber officinale.

\begin{tabular}{lcccc}
\hline & \multicolumn{2}{c}{ Ethanolic extract } & \multicolumn{2}{c}{ Tetracycline } \\
\cline { 2 - 5 } Species & MIC & MBC & MIC & MBC \\
\hline Staphylococcus aureus & 0.0024 & 0.625 & 0.98 & 15.63 \\
Staphylococcus aureus ATCC 25923 & 0.0024 & 0.156 & 0.25 & 1.96 \\
Bacillus subtilis IP 5832 & 0.625 & 1.25 & n.d. & n.d. \\
Bacillus subtilis ATCC 6633 & 0.3125 & 0.625 & 1.96 & 15.63 \\
Bacillus cereus & 0.3125 & 0.625 & 0.035 & 0.13 \\
Pseudomonas aeruginosa & 2.5 & 20 & 500 & 1000 \\
Pseudomonas aeruginosa ATCC 27853 & 10 & 20 & 7.82 & 62.5 \\
Proteus mirabilis & 2.5 & 2.5 & 125 & 125 \\
Proteus mirabilis ATCC 12453 & 2.5 & 2.5 & 15.63 & 31.25 \\
Escherichia coli & $>20$ & $>20$ & 1.96 & 3.91 \\
Escherichia coli ATCC 25922 & 20 & $>20$ & 0.98 & 3.91 \\
Salmonella enterica & 20 & 20 & 0.49 & 3.91 \\
Salmonella typhimurium & 20 & 20 & 1.96 & 3.91 \\
\hline
\end{tabular}

*Minimum inhibitory concentration (MIC) and minimum bactericidal concentration (MBC) values are given as $\mathrm{mg} / \mathrm{ml}$ for extract and $\mu \mathrm{g} / \mathrm{ml}$ for antibiotic; n.d. - not determined.

The ethanolic extract of $Z$. officinale demonstrated moderate to strong antibacterial activity, and showed stronger inhibitory effects against Gram-positive than Gram-negative bacteria $(\mathrm{p}<0.05)$. The results indicated that the most sensitive bacteria were the standard strain of S. aureus ATCC 25923 (MIC at $0.0024 \mathrm{mg} / \mathrm{ml}$ and MBC at $0.156 \mathrm{mg} / \mathrm{ml}$ ) and the isolate $S$. aureus (MIC at $0.0024 \mathrm{mg} / \mathrm{ml}$ and $\mathrm{MBC}$ at $0.625 \mathrm{mg} / \mathrm{ml}$ ).

The tested extract showed lower activity on the growth of Gram-negative bacteria (MIC and MBC ranged from $2.5 \mathrm{mg} / \mathrm{ml}$ to $>20 \mathrm{mg} / \mathrm{ml}$ ), the exception are the strains $P$. mirabilis, $P$. mirabilis ATCC 12453 where MIC and MBC value was $2.5 \mathrm{mg} / \mathrm{ml}$ and the isolate $P$. aeruginosa (MIC at $2.5 \mathrm{mg} / \mathrm{ml}$ ). AL-MARIRI and SAFI (2014) have tested $Z$. officinale in susceptibility of Gram-negative bacteria (E. coli, Proteus, etc.) and they have found how many isolates out of the tested number were sensitive to the presence of ethanolic extract and essential oil of this plant.

S. aureus ATCC 25923 and E. coli ATCC 25922, used in this conduction, were also the subject (amongst others) of EWNETU et al. (2014) study. They have tested synergistic effect of ginger extract and honey on bacteria and they suggest combining of these substances, because the results have shown that the effect is bigger than in the individual use. HASAN et al. (2012) tested methanolic and n-hexane extracts of $Z$. officinale against different 
microorganisms. They showed also that the extracts were more active against the Grampositive than the Gram-negative bacteria.

The effect of ethanolic and methanolic extracts of ginger were studied by BHARGAVA et al. (2012), and have demonstrated similar MIC values of ethanolic extract against tested bacteria. TAURA et al. (2014) have showed that the ethanolic extract of ginger was more effective on $S$. aureus (MIC at $100 \mu \mathrm{g} / \mathrm{ml}$ ), but it did not act against E. coli and P. aeruginosa. In another study done by NAJI and JASSEMI (2010) ethanolic extract of ginger showed the best effect against $P$. aeruginosa and $E$. coli. In our study, ethanolic extract showed the strongest effect on $S$. aureus. The antibacterial activity of aqueous, ethanolic, methanolic, hexane and ethyl acetate extracts of Z. officinale was studied by KAUSHIK and GOYAL (2011), and they determined low sensitivity of E. coli. AUTA et al. (2011) investigated ethanolic, cold water and raw extract of $Z$. officinale and demonstrated that the $P$. aeruginosa was more susceptible than $E$. coli, which is in accordance with our findings.

\section{Anti-biofilm activity}

The results of in vitro anti-biofilm activity of ethanolic extract of Z. officinale are presented in Table 2. The bacteria used in this part of investigation have been selected from the bacteria used for antibacterial activity depending on their biofilm formation potential.

Table 2. Anti-biofilm activity of ethanolic extract from Zingiber officinale.

\begin{tabular}{lccc}
\hline & \multicolumn{2}{c}{ Values $^{*}$} & \multirow{2}{*}{ BIC $_{\text {50 }}$} \\
\cline { 2 - 3 } Species & A & P & > 20 \\
\hline Pseudomonas aeruginosa ATCC 27853 & 1.321 & 89.499 & 19 \\
Proteus mirabilis & 0.110 & 52.632 & $>20$ \\
Escherichia coli ATCC 25922 & 0.262 & $>100$ & \\
\hline
\end{tabular}

*Values are given for extract concentration of $20 \mathrm{mg} / \mathrm{ml}$ : A - Absorbance of biofilm, $\mathrm{P}$ - Percentage of biofilm growth; Biofilm inhibitory concentration $\left(\mathrm{BIC}_{50}\right)$ in $\mathrm{mg} / \mathrm{ml}$.

Anti-biofilm activity is presented in three types of results. The influence on biofilm formation varied among the tested strains. P. aeruginosa ATCC 27853 formed the thickest biofilm (strong producer) and two other bacteria were classified as moderate biofilm producer (STEPANOVIĆ et al., 2000; HASSAN et al., 2011). The ethanolic extract of Z. officinale demonstrated moderate anti-biofilm activity, and the influence was the best on $P$. mirabilis were the $\mathrm{BIC}_{50}$ was at $19 \mathrm{mg} / \mathrm{ml}$. The percentage of $P$. aeruginosa ATCC 27853 biofilm reduction was 10.5 for the $20 \mathrm{mg} / \mathrm{ml}$ concentration of investigated extract $\left(\mathrm{BIC}_{50}>20\right.$ $\mathrm{mg} / \mathrm{ml})$.

Ginger extract was tested by KIM and PARK (2013) and the results against $P$. aeruginosa PA14 biofilm formation demonstrated positive effectiveness. YAHYA et al. (2013) found out that the ethanolic extract of $Z$. officinale inhibited $P$. aeruginosa biofilm formation under both aerobic and anaerobic environments.

Recent exploration came with the phenolic compounds isolated from Z. officinale being QSI (quorum sensing inhibitors). That was verified on P. aeruginosa MTCC 2297 (KUMAR et al., 2014). That is important because quorum sensing is playing significant role at food spoilage, biofilm formation, food-related pathogenesis, and ginger is well used foodstuff as spice in dry or fresh form. 


\section{CONCLUSION}

Z. officinale ethanolic extract has shown a wide range of influence on bacteria. Since it can be used in food, this investigation of ginger has confirmed its significance, especially in the area of influence on tested staphylococci where the result achieved was much better in compare with the previous investigations. The tested bacteria can also be food spoilage, and ginger extract had effect against them. Z. officinale is widely and constantly explored, and further investigation in other scientific areas will show more of its potentials.

\section{Acknowledgements}

This investigation was supported by the Ministry of Education and Science of the Republic of Serbia, grants No. III41010 and OI173032.

\section{References:}

[1] Ali, B.H., Blunden, G., TaniRA, M.O., Nemmar, A. (2008): Some phytochemical, pharmacological and toxicological properties of ginger (Zingiber officinale Roscoe): A review of recent research. Food Chem. Toxicol. 46, 409-420.

[2] AL-MARIRI, A., SAFI, M. (2014): In vitro antibacterial activity of several plant extracts and oils against some Gram-negative bacteria. Iran. J. Med. Sci. 39: 36-43.

[3] ANDREWS, J.M. (2005): BSAC standardized disc susceptibility testing method (version 4). J. Antimicrob. Chemother. 56: 60-76.

[4] Auta, K.I., Galadima, A.A., Bassey, J.U., Olowoniyi, O.D., Moses, O.O., Yako, A.B. (2011): Antimicrobial properties of the ethanolic extracts of Zingiber officinale (Ginger) on Escherichia coli and Pseudomonas areuginosa. Ann. Biol. Res. 2, 307-311.

[5] Bhargava, S., Dhabhai, K., Batra, A., Sharma, A., Malhotra, B. (2012): Zingiber officinale: Chemical and phytochemical screening and evaluation of its antimicrobial activities. J. Chem. Pharm. Res. 4: 360-364.

[6] Chaieb, K., Kouidhi, B., Jrah, H., Mahdouani, K., Bakhrouf, A. (2011): Antibacterial activity of thymoquinone, an active principle of Nigella sativa and its potency to prevent bacterial biofilm formation. BMC Complement. Altern. Med. 11: 29.

[7] Donlan, R.M. (2002): Biofilms: microbial life on surfaces. Emerg. Infect. Dis. 8: 881890.

[8] Donlan, R.M., Costerton, J.W. (2002): Biofilms: survival mechanisms of clinically relevant microorganisms. Clin. Microbiol. Rev. 15: 167-193.

[9] Ewnetu, Y., Lemma, W., Birhane, N. (2014): Synergetic antimicrobial effects of mixtures of Ethiopian honeys and ginger powder extracts on standard and resistant clinical bacteria isolates. Evid. Based Complement. Alternat. Med. 24: 1-8. http://dx.doi.org/10.1155/2014/562804.

[10] FRANK, J.F. (2001): Microbial attachment to food and food contact surfaces. Adv. Food Nutr. Res. 43: 319-370. 
[11] Habib, S.H.M., MaKPOL, S., Hamid, N.A.A., Das, S., NGah, W.Z.W., Yusof, Y.A.M. (2008): Ginger extract (Zingiber officinale) has anti-cancer and anti-inflammatory effects on ethionine-induced hepatoma rats. Clinics. 63: 807-813.

[12] Hasan, H.A., Rasheed RaAuf, A.M., Abd RaziK, B.M., Rasool Hassan, B.A. (2012): Chemical composition and antimicrobial activity of the crude extracts isolated from Zingiber officinale by different solvents. Pharmaceut. Anal. Acta. 3: 9.

[13] Hassan, A., Usman, J., Kaleem, F., Omair, M., Khalid, A., IQbal, M. (2011): Evaluation of different detection methods of biofilm formation in the clinical isolates. Braz. J. Infect. Dis. 15: 305-311.

[14] Hood, S.K., ZotTola, E.A, (1995): Biofilms in food processing. Food Control 6: 9-18.

[15] KIM, H.S., PARK, H.D. (2013): Ginger extract inhibits biofilm formation by Pseudomonas aeruginosa PA14. PloS one, 8, e76106.

[16] KAUShiK, P., Goyal, P., (2011): Evaluation of various crude extracts of Zingiber officinale rhizome for potential antibacterial activity: a study in vitro. Adv. Microbiol. 1: 7-12.

[17] Kumar, V.N., Murthy, P.S., Manjunatha, J.R., Bettadaiah, B.K. (2014): Synthesis and quorum sensing inhibitory activity of key phenolic compounds of ginger and their derivatives. Food Chem. In Press, http://dx.doi.org/10.1016/j.foodchem.2014.03.039

[18] LEWIS, K. (2001): Riddle of biofilm resistance. Antimicrob. Agents Chemother. 45: 9991007.

[19] NAJI, T., JASSEMI, M. (2010): Comparison between antibacterial effects of ethanolic and isopropyl: hexan (7:3) extracts of Zingiber officinale Rose. World Acad. Sci. Eng. Technol. 4: 673-676.

[20] O'Toole, G.A., Kolter, R. (1998): Initiation of biofilm formation in Pseudomonas fluorescens WCS365 proceeds via multiple, convergent signalling pathways: a genetic analysis. Mol. Microbiol. 28, 449-461.

[21] Quave, C.L., Plano L.R.W., Pantuso, T., BennetT, B.C. (2008): Effects of extracts from Italian medicinal plants on planktonic growth, biofilm formation and adherence of methicillin-resistant Staphylococcus aureus. J. Ethnopharmacol. 118: 418-428.

[22] Ross, I.A. (2005): Medicinal Plants of the World. Humana Press, Totowa, New Jersey: 507-560.

[23] Sandasi, M., LeOnard, C.M., Viljoen, A.M. (2010): The in vitro antibiofilm activity of selected culinary herbs and medicinal plants against Listeria monocytogenes. Lett. Appl. Microbiol. 50: 30-35.

[24] Sarker, S.D., NAHAR, L., Kumarasamy, Y. (2007): Microtitre plate-based antibacterial assay incorporating resazurin as an indicator of cell growth, and its application in the in vitro antibacterial screening of phytochemicals. Methods 42: 321324.

[25] Stepanović, S., Vuković, D., Dakić, I., Savić, B., Švabić-Vlahović, M. (2000): A modified microtiter-plate test for quantification of staphylococcal biofilm formation. $J$. Microbiol. Methods 40, 175-179.

[26] Stollova, I., Krastanov, A., Stoyanova, A., Denev, P., Gargova, S. (2007): Antioxidant activity of a ginger extract (Zingiber officinale). Food Chem. 102: 764-770. 
[27] Taura, D.W., Lawan, S., Gumel, S.M., Umar, S., SAdisu U.F. (2014): Anti bacterial activity of ethanolic extract of Zingiber officinale and Pipper nigrum against some clinical isolates. Commun. Appl. Sci. 2: 52-64.

[28] YahyA, M.F.Z.R., SAIFUdDIN, N.F.H.A., HAMID, U.M.A. (2013): Zingiber officinale ethanolic extract inhibits formation of Pseudomonas aeruginosa biofilm. Int. J. Pharm. Bio. Sci. 3: 46-54. 